\title{
Od e-izobraževanja k m-izobraževanju
}

Ko govorimo o izobraževanju, se $v$ bistvu ukvarjamo s prihodnostjo ljudi, njihovo osebno varnostjo in preživetjem. Izobrazba človeka odločilno vpliva na to, kako bo lahko v "družbi znanja" preživel. P. Drucker pravi: "Naslednja družba je družba znanja. Osnovni vir družbe bo znanje in delavci z znanjem bodo glavna skupina delovne sile. Imela bo tri glavne značilnosti:

- ne bo imela mej, kajti znanje se prenaša še laže kot denar,

- socialna mobilnost navzgor bo možna za vsakega prek lahko dostopne formalne izobrazbe,

- potencialna bo vsakemu na razpolago vzpon ali padec. Vsakdo si bo lahko pridobil "proizvodna sredstva", to je znanje zahtevanov službi, ne bo pa mogel vsak zmagati...

Naslednja družba že ima vpliv velikanskega pomena: dovoljuje znanju, da se v trenutku širi in ga s tem napravi dostopnega vsakomur. $\check{C}$ e upoštevamo, kako lahko in s kakšno hitrostjo se širijo informacije, ugotavljamo, da bo morala biti vsaka institucija sposobna tekmovati v svetovnem merilu - ne le podjetja, ampak tudi šole, bolnice, državni organi itd. - čeprav bo še naprej delovala na lokalni ravni." (Drucker, The next society, The Economist, November 3rd 2001, str. 4)

Vsak človek posebej in tudi ustanove se bodo vedno bolj zagrizeno borile za znanje, človeku bo znanje zagotavljalo preživetje in kakovost življenja, znanje bo vplivalo na poslovne uspehe ustanov in jih branilo pred bankrotom. Dirko za znanjem povečuje tudi dejstvo, da ozka strokovna znanja ne zadoščajo več za uspeh in ne zagotavljajo zaposlitve. Npr. strojni inženir mora

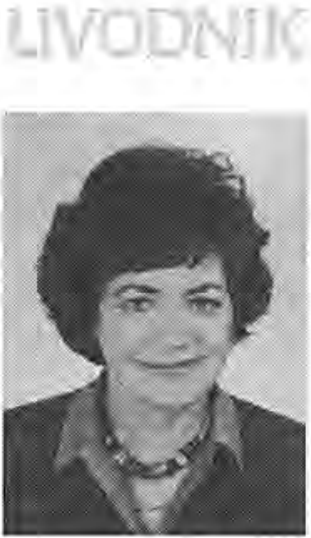

dr, Ana Krajnc obvladati tudi psihologijo ljudi v okolju, ki mu namenja svoje izdelke, socialno klimo ljudi, kulturne navade, tradicijo in zgodovino okolja, antropologijo in š kaj. Potrebe po znanju se hitro množijo, Večinoma so ljudje že zaslutili, da jih na star način (s tečaji in drugimi skupinskimi oblikami izobraževanja) ne moreja več zadovoljiti. Prav sem so usmerjena številna prizadevanja za razvoj študija na daljavo, eizobraževanja in m-izobraževanja v Evropi in po svetu.

E-izobraževanje (elektronsko) je začelo prodirati $v$ letu 1995, ko so na svetovnem spletu ponudili programe za diplome višjih šol, univerz in razne krajše oblike dopolnilnega študija. Večino študijskega časa so ljudje preživeli za pisalno mizo, pred računalnikom. Kraj izobraževanja ni bil fleksibilen. Tudi čas je bil včasih vnaprej določen. Zato so si morali čas za študij posebej rezervirati. Slaba stran takega izobraževanja so bile enosmerne komunikacije. To je bila že prej hiba študija na daljavo. Vsak študent je sprejemal prek interneta posredovano študijsko snov, ni pa imel možnosti, da bi se nanjo odzval, sporočil svoje gledanje in razumevanje učne snovi. Lahko je samo sprejemal, ni pa mogel oddajati. Elektronska pošta in "klepetalnice" so enostransko navezo v študiju dopolnile. Še vedno pa so študentje odvisni od lokacije stacionarnega telefona.

E-izobraževanje je veliko pripomoglo $h$ globalizaciji učenja in nadvse povečalo dostopnost znanja. Tako izobraževanje ne pozna meja, znanje postane dosegljivo vsakomur, ki pozna jezik programa in ima dostop do 
računalnika. Demokratizacija izobraževanja se je razmahnila. Študent lahko študira po svoji izbiri. Profesor na Frei Universität v Berlinu je izjavil, da nikoli ne bi mogel v predavalnico natrpati 250.000 študentov (zlasti ne tako različnih), kolikor jih obišče njegovo domačo stran o tridesetletni vojni na internetu (H. Dichanz: $E$ learning, Düsseldorf, 2001).

$V$ začetku leta 2002 so začeli spremljati mobilni študij na Norveškem, v Nemčiji, Italiji in na Irskem. Leto prej je steklo 30 projektov priprave programskih orodij za mobilne telefone in žepne osebne računalnike NOKIA in Ericsson $v$ povezavi $z$ univerzami $v$ več državah Evrope, Avstralije in Severne Amerike. Prostor nam ne dopušča, da bi navajali razne internetne strani vseh teh programov mobilnega študija.

Pomanjkljivosti prejšnjih oblik množičnega izobraževanja je dopolnilo m-izobraževanje (mobilno), baterijsko ali brezžično izobraževanje. Večina ljudi čuti, da jim manjka znanja, ne vedo pa, kako priti do njega. Nove možnosti za izobraževanje odpirajo nove brezžične elektronske naprave, kot je žepni osebni računalnik, povezan z mobilnim telefonom. Izobraževanje lahko podpremo tudi neposredno s programi SMS in WAP. Najšsirše dostopna sodobna tehnologija je mobilni telefon. Mobitel ima trenutno v Sloveniji I,254.000 naročnikov.

Prednosti mobilnega telefona so množičnost in skrajno prilagodljiva uporaba. Ljudje ga uporabljajo povsod, kjer se znajdejo: na avtobusih, cesti, v avtu, restavraciji, čakalnicah, na vlaku, $v$ naravi itd. Izobraževanje prek mobilnega telefona ali m-izobraževanje postane integrirano v življenje in je s tem tudi doživljajsko. podprto, učinkovitejše, bolj spontano in prijetnejše. Prožnost učenja ljudi se poveča, kraj in čas izobraževanja postaneta povsem svobodna in odvisna od osebne izbire.
Dvosmerne komunikacije so pri m-izobraževanju zakonitost. Sprotno motiviranje, komentarji učne snovi, preverjanje znanja in socialni stiki se odvijajo sproti ob ponujeni učni snovi večinoma prek programov SMS ali WAP in elektronske pošte, Prek mobilnega telefona se študentje povezujejo med seboj, $z$ mentorjem in administracijo, pošiljajo $v$ ocenjevanje svoje izdelke, Oglasijo se lahko kadarkoli od kjerkoli, saj je mobilni telefon vedno $z$ njimi ( $T$. Kristiansen: M-learning, Experiences from the use of WAP as a supplement in learning, Oslo, 2001).

Mobilno izobraževanje potrebuje učni scenarij in didaktično zgradbo učne snovi, prilagojeno za mobilno izobraževanje. Poleg mobilnega telefona potrebujemo še žepni osebni računalnik. Snovalci najnovejšega mobilnega izobraževanja na Norveškem uporabljajo žepni osebni računalnik Compaq iPAQ tip 3603, 3660, in 36650 skupaj z mobilnim telefonom Ericsson T39 in Ericsson R580. Oprema je tehnološko tako dovršena, da je uporaba zelo preprosia in dostopna vsakemu človeku. Pravilne odgovore pri testih in didaktičnih predlogah za preverjanje znanja izbira študent samo z dotikom ekrana. Podobno izbira tudi med tekstom, predavanjem (zvočno) in slikami ali videom. Izbira sebi ljubšo pot za študij.

Tehnologija se spreminja v razmikih po nekaj tednov in z njo tudi modeli izobraževanja: od študija na daljavo, elektronskega izobraževanja do mobilnega izobraževanja. Mobilno izobraževanje se je razvilo v zadnjih dveh letih. $V$ Sloveniji imamo dejanske možnosti za mobilno izobraževanje, mobilni telefon je popularen, treba mu je dati usebino. Mlad človek, ki ga je zavrgla selekcija našega solskega sistema, se svobodno lahko dokoplje do znanja prek mobilnega študija. Tudi ljudje srednjih let in starejši lahko na ta način potešijo svoje potrebe po znanju. 